\begin{tabular}{c} 
DIALOGUE OF HEART: \\
Interreligious Dialogue through Rumi's Poetry \\
Mochammad Maola \\
Universitas Gajah Mada \\
Email: maolamochammad@yahoo.com \\
\hline
\end{tabular}

\begin{abstract}
Living in harmony is required in a society which is characterized by cultural and religious diversity. It requires dialogue skills in various aspects of life during the day for allowing a sense of appreciation among humans and can be embedded within each other. Interreligious dialogue is a part of the disciplines covered in the field of religious studies. Indeed, the approach of interreligious studies is among the alternative mechanism in dealing with defamation of conflict between Islam and non-Islamic religions. This case needs to be dived so that alternative approaches are scattered in applying the dialogue between religions. Rumi (Mewlana Jalaluddin Rumi) is a famous name of Muslim mystics and great Sufi scholar with many adherents. He has written many books, especially in poetry. The w ay Rumi universally see religion and humankind through his poetry is exciting to be understood as a dialogue of heart. In order to reasoning, this paper will use the help of reading by Swidler and Pruitt. This paper uses literature review tow ard Rumi's book entitled Mathnawī. From the findings and discussion, it can be concluded that mysticism introduced inter religious dialogue through poetry, and put heart or soul as the tool to perform interreligious dialogue.
\end{abstract}

Keywords: Interreligious Dialogue, Dialogue of Heart, Rumi, Poetry

DOI: http://dx.doi.org/10.20414/ujis.v22i1.312

\title{
Introduction
}

EVERY MISUNDERSTANDING and misleading of the undelivered message requires dialogue as a mutual way of understanding and perceiving. A lot of dialogue, conciliation, memorandum of understanding, has been done to solve many problems. Some work and some do not. Beside of lingual dialogue, there is another 
kind of dialogue that could be used as an alternative. In this study, my focus is on the dialogue of heart as described by Swidler ${ }^{1}$ and using Rumi as a figure who used to create many poetries as a tool of interreligious dialogue. I choose Rumi because Rumi is one of the most widely read poets in North America since more than a decade ago. After more than eight centuries, further away from the $\mathrm{ebb}$, the popularity of this mystical poet among Muslims and nonMuslims has risen very rapidly. ${ }^{2}$

Mewlana Jalaluddin Rumi has the full name of Mewlana Jalāl al-Dīn Rūmī Muhammad ibn Hasin al-Khatțābī al-Bakrī (Jalaluddin Rumi) or sometimes called by the name Rumi, was a Sufi poet who was born in Balkh (now Afghanistan) on the 6th of Rabi' al-Awwal 604 Hijri, or dated 30 September 1207. His father was a descendant of Abū Bakr (Prophet Companion), called Bahauddin Walad. While his mother was a descendant of the royal family of Khwarazm. Rumi's father is a devout scholar who was able to forward-looking, and a famous teacher in Balkh. When Rumi was three years old, because of threats by Mongol invasion, his family left Balkh through Khurasan and Syria, to the Rum province in central Anatolia, which is part of Turkey now. They settled in Konya, the provincial capital of Rum. On the adventure and refuge, the family had stopped in the city of Nishapur which is the birthplace of poet and mathematician Omar Khayyam. In this city, Rumi met with Fariduddin Attar, who foresaw Rumi would be famous someday, that will ignite the fire of passion Godhead. In $1244 \mathrm{M}$, Rumi met with another spiritual sheikh, Shamsuddin of Tabriz, which turns him into perfect in mysticism. After Shamsuddin died, Rumi then met with the Husamuddin Ghalabi and inspired him to write his great spiritual experience in

1 Leonard Swidler, "The Dialogue Decalogue: Ground Rules for Interreligious Dialogue," Horizons 10, no. 2 (1983): 348-351.

${ }^{2}$ M Mannani, "The Metaphysics of the Heart in the Sufi Poetry of Rumi," Religion \& Literature 42, no. 3 (2010): 161-168; Mohammed Rustom, "The Metaphysics of the Heart in the Sufi Doctrine of Rumi," Studies in Religion/Sciences Religieuses 37, no. 1 (March 2008): 3-14, https://doi.org/10.1177/000842980803700101. 
his work Mathnawi al-Ma'nawī. He dedicated his work to Husamuddin until his death in 1273 AD. ${ }^{3}$

Rumi's famous collection of poems called al-Mathnawī al$M a$ 'nawi supposedly is a revolution against kalam science which lost the spirit and strength. Its contents also criticized the pace and direction of philosophy which tends to exceed the limits, castrating feelings and cult ratio. Admittedly, that Rumi poetry has its characteristics other than Sufi poets. Through his poetry, Rumi said that the understanding of the world just might be obtained through love and not solely through physical work. In his poetry, Rumi also said that God, as the only objective, has no equal. Another characteristic that distinguishes poetry of Sufi poet Rumi with the other works is often he started his poetry by using stories. However, this does not mean he wanted to write narrative poems. The stories were used as a statement of thoughts and ideas. There are many found the stories in a Rumi poem that seems different but has parallel symbolic meaning. Some historical figures he had displayed not in the historical purpose, but he displays them as symbolic images. Figures such as Joseph, Moses, Jacob, Jesus, and others displayed as a symbol of the beauty of the soul that reached enlightenment. Moreover, indeed such famous figures as a person are overwhelmed by divine love. ${ }^{4}$

Rumi is a productive Sufi. Also, as a preacher and teacher, he also wrote books of Sufism and majority are poetry or prose. Therefore, it is only natural that he dubbed the great Sufi poets. Rumi literary works practically very plural; in his Dīwān Shams Tabrizi $\bar{l}$, there are approximately 2500 words; Mathnaw $\bar{\imath}$ about 25,000 stanzas in the poem; and $R u b \bar{a}$ ' $i y \bar{a} t$ approximately 1600 rows is genuine. In summary, the works of Rumi can be classified into six pieces of work; three great works and three relatively small works. The major works are as follows: 1) Maqālāt Shams Tabrizin. This work contains mystical dialogue between Shams Tabrizin as the teacher and Rumi as the disciple. 2) Dīwān Shams

\footnotetext{
${ }^{3}$ Muhammad Este'Lami, "Rumi and the Universality of His Message," Islam and Christian-Muslim Relations 14, no. 4 (October 2003): 429-524, https://doi.org/10.1080/0959641032000127588.

${ }^{4}$ Fariba Enteshari, "Rumi's Poetry: The Journey Toward Meaning and Transformation" (Doctoral Thesis, Fielding Graduate University, 2013).
} 
Tabrizin, this book was composed by Rumi when he parted ways with his teacher Shams Tabrizin, which contains idol in addition to the memory of beloved teacher and friend. 3) Mathnawi al$M a^{\prime} n a w \bar{i}$, this work contains the basic teachings of Sufism of Rumi which is very deep. The followers of Rumi regard it as an introduction to the inner meaning of the Qur'an. This work was conveyed in poetic language creatively through apologetics, anecdotes, and legends. While the works of Rumi relatively small among others: 1) Rub a iyāt, Rumi poems delivered in the quatrain form (4 lines rhymes). 2) Maktūba $\bar{a}$, this work is a collection of letters addressed to Rumi and to avenge colleagues or followers. 3) Fīhi $m \bar{a}$ fïhi, this work is Rumi lectures on Sufism to his followers who are members of the congregation. ${ }^{5}$

\section{Dialogue of Heart}

Dialogue nowadays is an essential value of understanding others. Dialogue is a conversation about general topics between two or more people with different views. The primary goal is for each participant to learn from others so that he or she can change and develop. Swidler describes a historical movement of religions to arrive at the awareness of religious freedom and challenges for dialogue as a necessity today. Therefore, according to Swidler, religious pluralism is an awareness of religious plurality, which religions showed an interdependence which established relationships and dialogue is a necessity for religions. Swidler also describes a chronology of interest in the development of religious freedom and dialogue. ${ }^{6}$ According to him, in full religious freedom yet until the end of the $18^{\text {th }}$ century and authentic dialogue has just happened in the $20^{\text {th }}$ century. It happens for many reasons. For example, although Christian thinkers of the first centuries tended to affirm religious freedom, it soon changed when Constantine the Great made Christianity the religion of the empire. Historically, new religious freedom is considered as a human right by the

\footnotetext{
${ }^{5}$ Annemarie Schimmel, "Mystical Poetry in Islam: The Case of Maulana Jalaladdin Rumi," Religion $\mathcal{E}$ Literature 20, no. 1 (1988): 67-80, https://www.jstor.org/stable/40059367.

${ }^{6}$ Swidler, "The Dialogue Decalogue."
} 
events of the French Revolution and the founding of the United States.

In the implementation of the dialogue, although a form of dissent, views, and ideas regarding cases deal with between the parties involved, the nature of ethics requires open dialogue, guarded, and mutual respect. In another discourse, Swidler said, "learning more truth about the subject from the other." Swidler further stated that the concept of genuine dialogue is not confined to the religious representatives who are experts in a particular field but let dialogue also involving all ranks and levels of society. Only through this approach, the ideals of dialogue can be developed because a manifestation of consciousness to understand and learn from others. Swidler stated that the results of the dialogue not only embodies the meeting which took place in an atmosphere of mutual respect, but also the foundation for the clear up misunderstanding and appreciate the value of any party giving rise to an attitude of reciprocity and the consciousness of that group of human unity sharing life together. ${ }^{7}$ Therefore, he proposes four kinds of dialogue; the dialogue of head, dialogue hand, the dialogue of heart, dialogue of the holy. In this paper, I argue that the dialogue of heart from Swidler is the best tool to do interreligious dialogue because it is focusing on heart, love, and respect.

Likewise, Pruitt suggests to include a more inclusive mechanism for shared meaning, definition of dialogue needs to include nonverbal methods of communication, such as music. ${ }^{8}$ In his article, Pruitt used the concept of dialogue, covering a situation in which two or more people using non-violent methods to express and exchange of meaning. It includes dialogue involving music and verbal processes, as evident in the case studies by Pruitt. Many scholars, practitioners, and policymakers have suggested that art and music can foster and encourage dialogue, promote positive social change. If some people, based on social

\footnotetext{
${ }^{7}$ Ibid.

${ }^{8}$ Lesley Pruitt, "Creating a Musical Dialogue for Peace," International Journal of Peace Studies 16, no. 1 (2011): 81-103, accessed February 6, 2019, https://research.monash.edu/en/publications/creating-a-musical-dialogue-forpeace.
} 
hierarchy and language skills, could not participate in the dialogue spoken in a way that is fair and inclusive, perhaps at least some cases of music can offer them other methods to contribute. ${ }^{9}$ Indeed, some scholars have suggested that music may have an important role to play in communicating across differences because it does not require translation. In this case, poetry as dialogue is already introduced by Paul Celan. ${ }^{10}$

\section{Rumi's View of Pluralism in Mathnawī}

Rumi and The Real (al-Haq)

Rumi poetry as the result of imagination and appreciation of religion, full of meaning that could not be read textually only. Even it will be one if given the significance of reading the text only. Error by mistake in understanding the text finally led many people to conclude that Rumi apostate even pagan. Inability to understand the thinking of Rumi contained in the text of the poem until now he had to accept the charges as an infidel. ${ }^{11}$ One of the thoughts which are often misunderstood is on its views of other religions such as expressed as follows:

My soul, O Light that shines bright
It is not far from me, really not so much
This love, O Light that shines bright
Are not as far away from me, really not so much
Look to this turban, I wear on my head
See too, to this belt, my belt at the waist
I bring this belt (actually) I did not bring anything
Actually, I'm bring ing the Light which is not far from me
I am a Muslim, I also Jews and Christians
I put my trust in al-Haq (The Real) Most High
It's not far from me
I have nothing but God the One
Either in mosques or churches even in places where idols. ${ }^{12}$

${ }^{9}$ Ibid.

${ }^{10}$ Nicholas J. Meyerhofer, "The Poetics of Paul Celan," Twentieth Century Literature 27, no. 1 (85): 72; James K. Lyon, "Paul Celan and Martin Buber: Poetry as Dialogue," Publications of the Modern Language Association of America 86, no. 1 (1971): 110-120.

${ }^{11}$ Ahmad Jalali, “Jalaluddin Rumi's Religious Understanding: A Prelude to Dialogue in the Realm of Religious Thought," Diogenes 50, no. 4 (2003): 127-134.

12 Jalāl al-Dīn Rūmī, The Mathnawi of Jalalu'ddin Rumi, ed. Reynold Alleyne 
Most people often perceive the poem as Rumi recognition as a religion that justifies all without seeing in their entirety. Which is often revealed only the phrase "I am a Muslim, I also Jews and Christians" as legitimate to accuse Rumi and Mevlevi congregation as heresy, instead of seeing God as the Ultimate Truth or The Real.

\section{Rumi and Religious Pluralism}

Rumi in other poems he says;

The lights were different,

But the light was the same;

It comes from the Top

If you keep staring at the lights

You will be confused; because that appears sighting number and diversity

Settle your eyes on the Light you will escape the dualism inherent in the finite body

O you who are the core existence

Conflicts between the Muslims, Zoroastrians and Jews depend on the establishment

Some Indians see an elephant

To show up in the arena

Because it is impossible to see for

So every person touched by palms

The hand that touches the trunk would say;

These animals such as water pipes

Who fingered his ear would say

He was a fan and so on. ${ }^{13}$

Textually, Rumi was indeed impressed to justify all religions. However, if the language is parsed, then the first poem of Rumi has presupposed a turban and a belt with the Light or God. If only that it would argue that Rumi was evened gods with objects that do not mean anything. Poetry, using the assumption of course, is also seen the aspect of what he equated that in linguistics called the wajh shibh. Thus the meaning of the poem is that Rumi in terms of closeness to God the same as belt and turban that he had brought with him wherever he goes. He was integral in any circumstances. Likewise, in another poem, Rumi stated that he

Nicholson, trans. Reynold Alleyne Nicholson (England: E. J. W. Gibb Memorial Trust, 1990).

${ }^{13}$ Ibid. 
considers pharaohs someone who recognizes the existence of God. This recognition as Rumi relates to God's destiny to himself who made the Pharaoh as a lesson for humans. He is not saying that the Pharaoh a devout but more than that he was told that Pharaoh was destined for it, but it is not fate itself. Anyone could not change what God has destined for everyone. As long as one to worship the one God then there is no way to regard as infidels or apostates. The last poem Rumi likens the living God with a feeling of an elephant. Someone will have each other's perceptions about God as to where he said the elephant as water pipes, fans and so on. However, what should be noted is that it remains the elephant one. That is, however, Rumi respect the opinion, religion and the way people worship God, he is of the opinion that a person would be correct if he recognizes the One God. ${ }^{14}$ In other words, whatever their religion and identity, as a formalist designation as long as he recognizes that God is one, he is a Muslim.

\section{Rumi and Religion of Love}

Rumi revealed;

Love is a boundless sea. The sky is simply flake mere froth

Know this: the sky rotates as the wave of love

If there is no love, the world will freeze. ${ }^{15}$

As a thinker, poet Rumi once tried to give notions that there would be no life without love. If a person lives without any sense of love, then life will never be peace and human life will be a mess. Humans will live in fear of their neighbors. To build love in the world as Rumi's sacrifices an absolute thing to do. There is no love without sacrifice. If it were not for love, how something organically transformed into plants? How will plants sacrifice themselves for the sake of obtaining the spirit (animal)? How will spirit sacrifice himself for the sake of obtaining The Spirit who impregnate Mary? All of that will be frozen and stiff like snow. It could not fly as well as looking like a grasshopper in grassland. Each atom falls in love with the Most Perfect and rises to the top

14 Amin Sadr, "Love, Death, and Submission: The Role of the Reader in Rumi's" (Doctoral Thesis, The University of Chicago, 2014).

${ }^{15}$ Rūmī, The Mathnawi of Jalalu'ddin Rumi. 
like a budding ideal they were inaudible, actually is a praise song to the Glory of God. Besides, all the poetry of Rumi created in the context of the love of God. When love meets the person's heart, whatever the title is not essential to him.

Similarly, if it is associated with a religious identity, designation as a Muslim or non-Muslim for a heart full of love for God is not important. Even for him to do goods and worship God does not depend on the presence or absence of heaven. He was charitable and not because of fear of hell. Rumi was a Muslim for a just deed is hoping love for God alone. So that in the opinion of Rumi's view that in this world nothing will happen except by love. ${ }^{16}$

In the name of love, everything requires sacrifice. What is said by Rumi above is a form of sacrifice between creatures to another creature which ends on human needs. Sacrifices were made solely to a love of God the Almighty. Every creature created by God has a desire to meet soon and longing for the Creator origin. While Rumi was seen only as a mystic with the concept of love, the concept of love by Rumi always interpreted merely talking about man's relationship with God. So it is, and almost no one thought Rumi besides reveal about religious teachings to human relations through a poem. Indeed, apart from the teachings of the love of God embedded in his poetry, Rumi also teaches religious tolerance without blaming each other and felt utter. His poetry above is one of many poems that revealed that the love of God did not necessarily free and separated from the environment and nature. Religion by Rumi, if it is associated with religious life, then religion does not merely regulate the relationship with God as a creator but also the relationship with humans and other humans. All relationships with humans should be run from love. ${ }^{17}$ Hatred in humans is essentially a heart disease and would contaminate the human heart. Hearts were not clean and pure, so how he would be able to love God the Holy One. It is impossible for dirty things can meet the net. If dirt and heart disease should be treated and cured, Rumi strongly recommends that human life by making

${ }^{16}$ Sadr, "Love, Death, and Submission."

17 Ibid. 
love as a base, love that will eliminate all the prejudice and hatred that would only restrict and inhibit the human heart to know God. If life is a part of the pluralism tolerance, Rumi taught more than just tolerance in life. The need for humans to be kind thought to what happens with other human beings because no one knows that he is being tested. Otherwise, not all evil deeds are done by someone on his own. Rumi in this regard that humans do any behavior without he can resist it is the destiny of God to man and the test against other human beings.

It was as contained in his poetry:

Both Moses and Pharaoh is a devotee of Almighty

Even looked first to find the way

And the other loses its way

During the day Moses cried out to the Lord;

At midnight Pharaoh started moaning. ${ }^{18}$

In the expression above, Rumi positioned parallel between Moses and Pharaoh. He considers the Mosaic worship openly and unconsciously Pharaoh also recognized his authority depends on the Almighty. Moses in this poem is a symbol of a devout Muslim and was admitted to the Oneness of God is real. Meanwhile, Pharaoh is a symbol of man rebelled against God that he could not understand what happened to him as a divine destiny. He also can not reject himself as an apostate to God. His apostasy to God is according to the will and the knowledge of God. For Rumi, for human beings recognize the true God during which he was a servant of God. According to the view of Rumi, called someone as infidels, apostates, Jews, Christians, and others would not mean anything if he loves God the One. ${ }^{19}$

\section{Discussion}

The inclusive approach proposed by Rumi's Mathnawi poetry is a form of dialogue using the heart. Because poetry is a literary work that should be read sincere from the heart, and written from the deepest heart. In his works, Rumi writes with all the knowledge and spiritual experience. Rumi introduces Islam to the art of poetry which is beautiful, embracing people from other

${ }^{18}$ Rūmī, The Mathnawi of Jalalu'ddin Rumi.

${ }^{19}$ Este'Lami, "Rumi and the Universality of His Message." 
religions, and even look for the same point. Rumi deliberately chose The Real as the primary purpose of the whole human and did not choose the word of God. Even Rumi chose the religion of love as the bond between Muslims and others.

From the above, it can be seen that Rumi did not justify all religions. He just said that wherever a person loves God and obey Him, it is a true Muslim. According to Rumi, Muslim is a person who loves Allah and His Oneness. Muslims are not at the stage of admission alone, but he was unjust and disobedient to Allah by not running the command of Allah. Rumi respects other religions even align his position before God. Because everyone proceeds to the One God. Rumi outlook on religion will be more apparent when analyzing the whole poem is very well like in $R u b \bar{a}$ ' $i y \bar{a} t, F \bar{h} h i$ $m \bar{a}$ fìhi, or Dīwān Shams Tabrìzì. With unravel one by one word and then interpret the symbols it uses with a view deep from the heart.

Meanwhile, Mathnavi also touches the problematic issue of destiny. Islam itself divided into several groups in defining destiny, whether humankind is predestined or not. Jabbaria group said that every human is predestined and it is unchanged. Meanwhile, Qaddariya said the other way that every human kind destines them own life. However, this is not the main focus of the findings. The point is that every human should accept their destiny and other destiny, as it is the will of God. When someone meets Christian, Jew, etc. who has different belief it should be noted that he or she become Christian or Jew, not because of his or her fault; instead it was destined by God.

\section{Conclusion}

Reasonable dialogue discourse puts discipline of Comparative Religion Studies as an alternative approach in attaching any issues related to the relationship between religions. Indeed, the affirmation of unity and harmony of religious life is essential to continue and implemented in Indonesia which has diverse ethnic, religious and culture. It is because the dialogue between religions is the best opportunity for Muslim scholars uses to give meaning dialogue channel about the teachings of Islam to non-Islamic society which does not arise for libel against the Muslim community so dragged to the religious conflict. Even the dialogue 
is a conversation arena which served as a forum for argumentation of the validity of Islam. Muslim scholars naturally wise to cultivate and explore the phenomenon of religion from the perspective of theology based on the theological perspective and Comparative Religion, in addition to Sociology of Religion, Psychology of Religion, History of Religion, and Art on the condition that all of these disciplines argued the scientific and academic relied on Divine Revelation and patterns of thought seeks to give participants in the dialogue to review the facts of Islam and at the same time eliminate skepticism towards Islam.

In essence, the triumph of dialogue between religions in the context of the discipline of Comparative Studies Religion is not dependent on campaign solely doctrine but also influenced by the compilation of the argument that is consistent with the ratio continuing willingness to accept reasonable minds. In addition to spoken dialogue, a non-verbal dialogue is also needed. We can use music as exemplified by Pruitt, or with poetry like Rumi and other scholars. With the meaning of other words, Islam stresses the importance of open and exposes the human mind in order to delve the real fact in understanding the phenomena or issues about religion. Relying on dialogue between religions and ethics of dialogue that are mounted in the history of the Prophet Muhammad, the dialogue gives mean that there is no coercion of participants in the dialogue to accept the fact without elaborating. The primary field of dialogue indeed a conversation based on something religious perspective in addressing something particular issue; the final decision, however, returned to the participants in the dialogue that needs to assess the principle of truth offered by the religion. Foundations and principles of harmony are the obligations of Islam that present religious teachings in a friendly way to all nature. The teachings could be indoctrinated and disseminated through a dialogue between religious discourses in the context of Comparative Religion for which it has created glories of Islamic civilization.

A further conclusion of this study could be extended in various ways. Could poets in nowadays writing a poem to promote interreligious dialogue or through lyrics of songs from songwriter? Of course, they could. A lyric of interreligious 
dialogue can be found in many ways. For example, the shining of Liverpool forward, Mohammad Salah, makes Liverpool fans chanting:

Mo Sa-la-la-la-lah

Mo Sa-la-la-la-lah

If he is good enough for you

He is good enough forme

If he scores another few

Then I'll Muslim too

If he's good enough for you

He is good enough forme

He is sitting in the mosque

That's where I wanna be

\section{References}

Enteshari, Fariba. "Rumi's Poetry: The Journey Toward Meaning and Transformation." Doctoral Thesis, Fielding Graduate University, 2013.

Este'Lami, Muhammad. "Rumi and the Universality of His Message." Islam and Christian-Muslim Relations 14, no. 4 (October 2003): 429-524. https://doi.org/10.1080/ 0959641032000127588.

Jalali, Ahmad. “Jalaluddin Rumi's Religious Understanding: A Prelude to Dialogue in the Realm of Religious Thought." Diogenes 50, no. 4 (2003): 127-134.

Lyon, James K. "Paul Celan and Martin Buber: Poetry as Dialogue." Publications of the Modern Language Association of America 86, no. 1 (1971): 110-120.

Mannani, M. "The Metaphysics of the Heart in the Sufi Poetry of Rumi." Religion E Literature 42, no. 3 (2010): 161-168.

Meyerhofer, Nicholas J. "The Poetics of Paul Celan." Twentieth Century Literature 27, no. 1 (85): 72.

Pruitt, Lesley. "Creating a Musical Dialogue for Peace." International Journal of Peace Studies 16, no. 1 (2011): 81-103. Accessed February 6, 2019. https://research.monash.edu/en/ publications/creating-a-musical-dialogue-for-peace.

Rūmī, Jalāl al-Dīn. The Mathnawi of Jalalu'ddin Rumi. Edited by Reynold Alleyne Nicholson. Translated by Reynold Alleyne Nicholson. England: E. J. W. Gibb Memorial Trust, 1990. 
Rustom, Mohammed. "The Metaphysics of the Heart in the Sufi Doctrine of Rumi." Studies in Religion/Sciences Religieuses 37, no. 1 (March 2008): 3-14. https://doi.org/10.1177/ 000842980803700101.

Sadr, Amin. "Love, Death, and Submission: The Role of the Reader in Rumi's." Doctoral Thesis, The University of Chicago, 2014. Schimmel, Annemarie. "Mystical Poetry in Islam: The Case of Maulana Jalaladdin Rumi." Religion \& Literature 20, no. 1 (1988): 67-80. https://www.jstor.org/stable/40059367.

Swidler, Leonard. "The Dialogue Decalogue: Ground Rules for Interreligious Dialogue." Horizons 10, no. 2 (1983): 348-351. 